\title{
Acute and Chronic Toxicity of Mercury Exposure in Seafood and Human Populations Near a Small-Scale Gold Mining Area
}

\author{
Sofia $^{1}$, Adi Heru Husodo ${ }^{2}$, Eko Sugiharto ${ }^{3}$ \\ ${ }^{1}$ Faculty of Medicine, Syiah Kuala University, Aceh, Indonesia \\ ${ }^{2}$ Department of Occupational and Environmental Health, Gadjah Mada University, Yogyakarta, Indonesia \\ ${ }^{3}$ Chemistry Department, Natural Sciences Faculty, Gadjah Mada University, Yogyakarta, Indonesia
}

\begin{tabular}{l}
\hline Article Info \\
\hline Article history: \\
Received Jun 8, 2016 \\
Revised Aug 10, 2016 \\
Accepted Aug 26, 2016 \\
\hline
\end{tabular}

\section{Keyword:}

Aceh

Exposure

Gold miner

Mercury

Toxicity

\begin{abstract}
Gold amalgamation processes using mercury were practiced in small scale gold mining activities in Krueng Sabee, Aceh Province. Seafood (fish, mollusc, shrimp) and human hair samples were collected to assess mercury concentrations. Acute and chronic toxicity symptoms which arise among the populations were observed as well as personal protective equipment used by gold miners. The range of mercury concentrations varied among fish, shrimp, and molluscs. The highest mercury levels were recorded in fish Puntius latristriga (172.299 $\pm 10.626 \mu \mathrm{g} / \mathrm{g}$ wet wt.), followed by mollusc, Polymesoda caroliniana (160.032 $\pm 0.522 \mu \mathrm{g} / \mathrm{g}$ wet wt.), fish R.kanagurta $(149 \pm 2.000 \mu \mathrm{g} / \mathrm{g}$ wet wt.), shrimp Penaeus monodon $(116.975 \pm 4.807 \mu \mathrm{g} / \mathrm{g}$ wet wt.). The variation of mercury concentrations in hair samples of 72 respondents were detected from $5.7 \mu \mathrm{g} / \mathrm{g}$ to $88.1 \mu \mathrm{g} / \mathrm{g}$. The most frequent acute and chronic intoxication symptoms documented were headache, muscle cramps, cough, and aphthous ulcers. Personal protective equipment which has correlation with high mercury levels in gold miners were respirator/mask, gloves, and apparel $(\mathrm{p}<0.05)$. All seafood samples exceeded $0.5 \mu \mathrm{g} \mathrm{Hg} / \mathrm{g}$ MoH Food and Drug Administration threshold level and hair samples over $10 \mu \mathrm{g} / \mathrm{g}$ as set by WHO tolerance limit.
\end{abstract}

Copyright () 2016 Institute of Advanced Engineering and Science. All rights reserved.

\section{Corresponding Author:}

Sofia,

Faculty of Medicine,

Syiah Kuala University,

Aceh Province, Indonesia.

Email: sofia@unsyiah.ac.id

\section{INTRODUCTION}

Exposure to mercury remains an environmental problems in the world. One cause of substantial elevations in human mercury exposure may come from working environments such as chlor-alkali plants, mining, manufacturing of gold extracted mercury, thermometer factories, and refineries. The Minamata Convention on Mercury in 2013 made regulations to protect human health and the environment from anthropogenic emission and releases of mercury and mercury compounds. In order to protect human health, the convention stressed the need to ensure proper management of mercury and prevention of Minamata Disease in the future that may be caused by mercury pollution.

Acute toxicity of mercury vapor can cause a severe lung damages which leads to death from hypoxia. The victim will experience ginggivitis, tremors, and erethism (memory loss, emotional lability, depression, insomnia, and shyness) [1]. Chronic toxicity after mercury exposure shows several signs and symptoms, i.e., general fatigue, weight loss, peripheral paresthesias, nephrotoxicity, cutaneous hyperpigmentation, and psychiatric abnormalities. Chronic exposure may occur via inhalation, ingestion, and parenteral or subcutaneous administration [2]. 
Methylmercury is a potent neurotoxin that can cause birth defects, learning disabilities, blindness, paralysis, loss of muscular control, and death. Contribution to the intake of mercury in human can occur through water in which methylmercury accumulates through the food chain with the primary source of seafood consumption such as fish, shrimp and molluscs. Krueng Sabee is one of the sub-districts located in the western part of Aceh Province, Indonesia which practices gold mining activities. Since 2008, there were many small-scale gold mining activities have been taking place in the villages. Uncontrolled used of mercury to extract gold from the ore is widespread around the villages near to their settlements. Mercury is released into the air by burning the amalgam and the waste is discharged into the Krueng Sabee river [3]. This river is 3-4 meters deep on average. Biota which are live in the river can accumulates mercury waste. Hence, communities near the river that eat catchments from the river can experience adverse effects by consuming mercury-contaminated seafood. The effects are hazardous to public health and can cause chronic body intoxication on an individual level. The most devastating tragedies related to mercury toxicity were documented in Minamata and Niigata, Japan in the 1950s and Iraq in the 1970s which resulted in hundreds of victims along these areas [2]. Due to the above problems, studies related to environmental and human health aspects are urgently needed in order to prevent widespread mercury poisoning. This study aims to determine mercury exposure in aquatic biota and human scalp hair as well as to evaluate the acute and chronic toxicity in populations near to the small-scale mining activity sites in Krueng Sabee, Aceh Province, Indonesia.

\section{RESEARCH METHOD}

\subsection{Study area and sampling sites}

Krueng Sabee sub-district is located in the western part of Aceh Province, Indonesia. Figure 1 shows study area and sampling sites of this study.

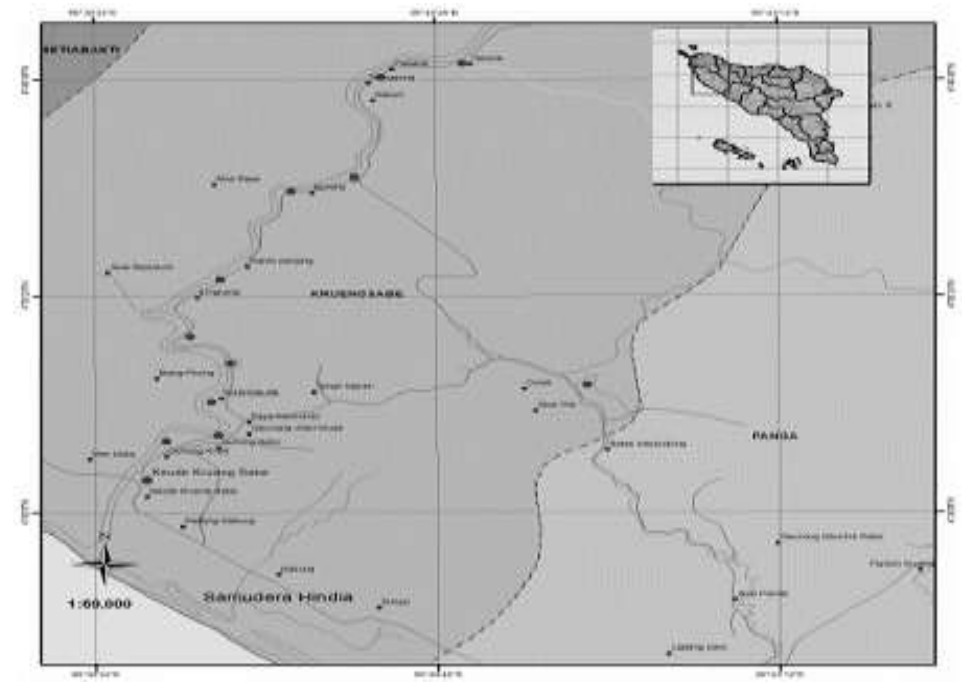

Figure 1. Study Area and sampling sites

Geographically, the district is defined by latitude $4^{\circ} 36^{\prime} 32^{\prime \prime} \mathrm{N}$ and longitude $95^{\circ} 40^{\prime} 36^{\prime \prime} \mathrm{W}$. Krueng Sabee is the most important gold mining sub-district in Aceh, which had 17 villages and 14,817 inhabitants in 2011 [4]. Sampling sites were chosen based on the high number of traditional gold ore processing plants at each site.

\subsection{Sample collection}

Seafood samples (fish, shrimp, and molluscs) were divided into two groups based upon methods of collection: fishing by fisherman, and buying in the traditional market near to the study area. Three species of fish and one species of shrimp were collected by local fishermen at several points along Krueng Sabee river, including Panggong, Sawang watershed, Keude Krueng Sabee, and Ranto Panyang. Fish spesies used for the study were Osteochilus sp, Puntius latristriga, Hampala makrolepidota. The shrimp species was Penaeus monodon. Samples collected from the traditional market included one species of mollusc Polymesoda caroliniana, and three species of fish, namely Rastrellinger kanagurta, Selaroides sp., and Euthynnus affinis. 
To investigate the effects of mercury on human health, hair samples were taken from 72 individuals from four villages. 17 individuals were sampled in Panggong, 17 individuals in Curek, 26 individuals in Paya Seumantok, and 12 individuals in Panton Makmur. All respondents had their vital signs examined. Informed consent and questionnaires were also distributed to the individuals prior to the identification of acute and chronic toxicity symptoms. Clinical symptoms on acute and chronic toxicity were determined from the interview process. Acute symptoms noted included: fatigue, headache, frequent aphthous ulcers, swollen gums, dark gums, loose teeth that easily fall out, swelling of the salivary glands, loss of sense of smell, chest tightness, chest pain, difficulty in breathing, cough, mouth numbness, nausea, vomiting, abdominal pain, diarrhea, turbid urine, bloody urine, pelvic pain, and pain during urination. Chronic toxicity symptoms noted included: somatosensory disturbances, headache, hearing impairment, tremors, muscle cramps, erythema, weight loss, anorexia, irritability, restlessness, depression, insomnia, and memory loss. For occupational health information, 29 gold miners were observed and interviewed for the use of Personal Protective Equipments (PPE) while working with mercury in their workplaces.

\subsection{Sampling procedure and mercury analysis}

Fish, shrimp, and mollusc species that are commonly eaten by the local population were caught and bought in the area of the Krueng Sabee sub-district. Upon purchase, the fish, shrimp, and mollusc samples were put in sealed plastic bags. Sampling and sample preparation followed EPA procedures [5]. The samples were dissected and transported in sealed containers to the Analysis Service Laboratory Unit, School of Chemistry, University Science of Malaysia (USM) in Penang, Malaysia. Cleaning and washing procedures for the glassware followed the APHA [6]. The individual tissues were digested using a MARS5Microwave digester with teflon-closed vessels. Approximately $0.5 \mathrm{~g}$ of fish, shrimp, and mollusc samples were weighed exactly and transfered into the teflon vessels. A volume of $10 \mathrm{ml}$ of concentrated $\mathrm{HNO}_{3}$ was added. After digestion, samples were diluted with up to $25 \mathrm{~mL}$ of ionized water in volumetric flasks. The mercury content was analyzed using a Cold VaporAAnalyst 200 Perkin-Elmer Atomic Absorption Spectrometer with flow injection mercury/hydride analysis. Calibration standards of mercury were prepared in the range of $10 \mu \mathrm{g} / \mathrm{L}$, $20 \mu \mathrm{g} / \mathrm{L}, 30 \mu \mathrm{g} / \mathrm{L}$. Duplicate determinations were made on all fish, shrimp, and mollusc samples.

Hair samples were put into some separate autosealable plastic bags with the age, sex, occupation, and residence history of the individuals, as indicated through an administration of a questionnaire. Hair strands were taken from the occipital region of the scalp using surgical-grade scissors. Each sample was stored in an autosealable plastic bag. In the laboratory, each hair sample was washed sequentially with acetone, deionized water, and acetone again, using three successive portions. Each of hair sample weighed approximately $1 \mathrm{mg}$ and was transferred into a $10 \mathrm{~mL}$ capacity PTFE digestion vial, and $5 \mathrm{~mL}$ of concentrated nitric acid was pipetted into the vial. The vial was loosely capped and the sample was left to digest at room temperature for about 20 minutes in order to reduce any foaming that might appear. Each vial was then tightly screw-capped and placed inside a microwave PTFE digestion tube and digested about 20 minutes in a CEM, MDS-2000 microwave digestion. After digestion finished, samples were left to make it cool at room temperature. Samples were then transfered into $100 \mathrm{~mL}$ volumetric flasks and a dilution made with $50 \mathrm{~mL}$ deionized water [7]. The mercury content in the hair was measured by Inductively Coupled Plasma-Mass Spectrometry (ICP-MS) X Series Thermo at the Centre for Advanced Analytical Toxicology Services (CAATS), University Science of Malaysia in Penang, Malaysia.

Quality assurance of samples was determined by using digestion blanks, replicate samples, pre-digestion spikes, and post-digestion spikes. Methods of detection limits were also carried out.

\subsection{Statistical analysis}

Data for the normality and equality of variance was assessed using the Kolmogorov-Smirnov test. One-way analysis of variance (ANOVA) was applied to compare its means between sex, as well as differences between species of biota and mercury concentration in muscle, followed by a Least Significant Difference (LSD) test. Linear regression was applied to determine the relationship among the four locations studied and hair mercury in respondents. One-sample t test was used to see differences between hair mercury and the WHO tolerance limit of $10 \mu \mathrm{g} / \mathrm{g}$. Differences in mean values were accepted as being statistically significant if $\mathrm{p}<0.05$.

\section{RESULTS AND ANALYSIS}

\subsection{Mercury concentrations in seafood}

Samples of seafood were analyzed for $\mathrm{Hg}$ levels. Figure 2 presents total $\mathrm{Hg}$ concentrations in fish, shrimp, and mollusc from Krueng Sabee. Mercury concentrations in fish, shrimp, and mollusc tissues were significantly different among species $(\mathrm{p}=0.013)$. 


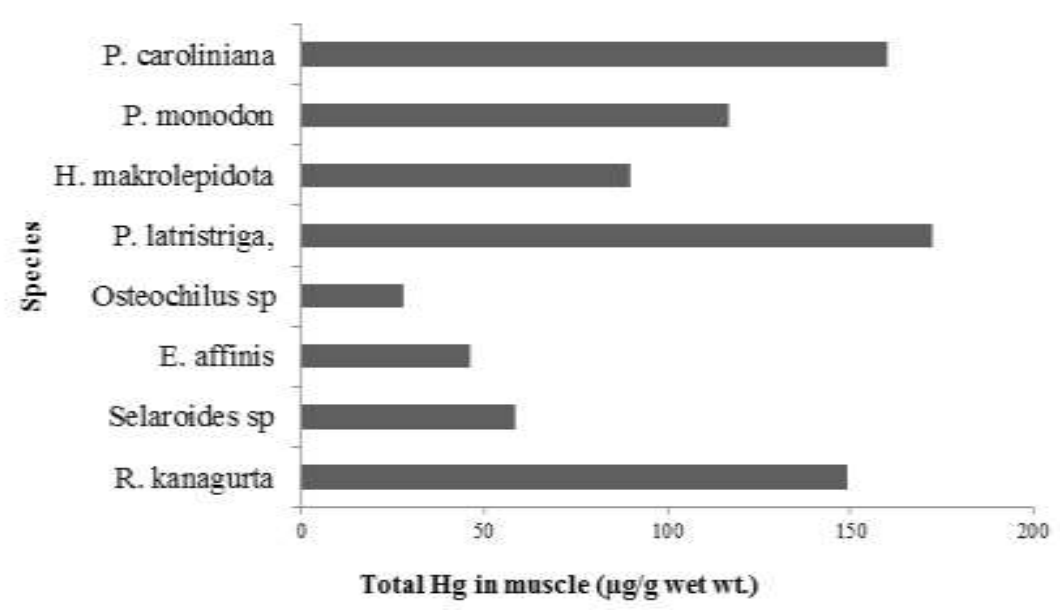

Figure 2. Total Hg concentrations in fish, shrimp, and mollusc from Krueng Sabee

Figure 2 shows that all seafood had $\mathrm{Hg}$ levels exceeding the MAFF guideline value $(0.3 \mu \mathrm{g} / \mathrm{g}$ wet wt.) [8]. The highest $\mathrm{Hg}$ levels were recorded in fish species $P$. latristriga $(172.29 \pm 10.62 \mu \mathrm{g} / \mathrm{g}$ wet wt.) which was caught from the Krueng Sabee watershed, followed by mollusc species $P$. caroliniana, fish species R.kanagurta, shrimp species, P. monodon, and fish species H. makrolepidota. The lowest Hg levels were recorded in fish species Osteochilus sp., while both Selaroides sp and Euthynnus affinis have almost the same $\mathrm{Hg}$ levels. Differences among species is possibly related to their habitats [9]. As P. latristriga is a species that lives in the Krueng Sabee river which receives mercury waste from gold mining activities in the area, the $\mathrm{Hg}$ concentrations found in this fish species was the highest in the study. High $\mathrm{Hg}$ concentrations were also found in shrimp species $P$. monodon, and mollusc species $P$. caroliniana, both of which are types of sedentary species that take food from the sediment of the contaminated river in the Krueng Sabee subdistrict. Overall, species found in this study were contaminated by mercury from gold mining activities. For human consumption, seafood from this study was unsafe to consume as it exceeds the MoH Food and Drug Administrasion which the treshold level is $0.5 \mu \mathrm{g} \mathrm{Hg} / \mathrm{g}$ [10].

Methyl mercury $(\mathrm{MeHg})$ is a compound which was found in fish organs and other seafood that represents a major source of organic mercury exposure for the population [11]. These results are similar to a study by Clifton which stated that $\mathrm{MeHg}$ can enter into the food chain and that the highest concentrations of $\mathrm{MeHg}$ can be found in long-living and large, predatory fish [2]. At the end of the food chain, human as top consumers become the victim of major organic mercury exposure by $\mathrm{MeHg}$-contaminated fish. Consumption of MeHg-contaminated fish been a public health disaster in Japan with a specific disease arising from this compound, known as Minamata disease. This disease occured in a person exposed to $\mathrm{MeHg}$ and it was discovered that this compound can cross both the blood-brain barrier and the placenta. Toxicity of $\mathrm{MeHg}$ may be examined as acute or chronic high-dose exposures as well as chronic low-dose exposures [2].

\subsection{Mercury levels in hair in human populations}

Hair mercury in respondents from four villages in the Krueng Sabee sub-district shows there is a relationship between location and hair mercury $(\mathrm{p}<0.05)$ (Figure 3$)$.

Figure 3 shows mean $\mathrm{Hg}$ concentrations in the hair of respondents from the four locations in Krueng Sabee. The mean $\mathrm{Hg}$ concentrations was recorded the highest in Paya Seumantok $(48.32 \mu \mathrm{g} / \mathrm{g})$ followed by Panton Makmur (42.05 $\mu \mathrm{g} / \mathrm{g})$, Panggong $(35.12 \mu \mathrm{g} / \mathrm{g})$ and Curek $(11.23 \mu \mathrm{g} / \mathrm{g})$. Regarding to that, the highest concentration of mercury in Paya Seumantok was influenced by many small-scale gold processing industries that present in the area.

The misuse of mercury during these activities can result in serious health hazards for the gold miners themselves as well as the the human population and natural environment nearby. Elevated mercury concentrations in humans can occur through three major potential routes of mercury exposure:(1) gold miners can have dermal exposure when they mix elemental mercury with gold ore; (2) elemental and inorganic mercury vapors can be inhaled when amalgams are heated; and (3) methylmercury can be consumed from contaminated fish [12]. 


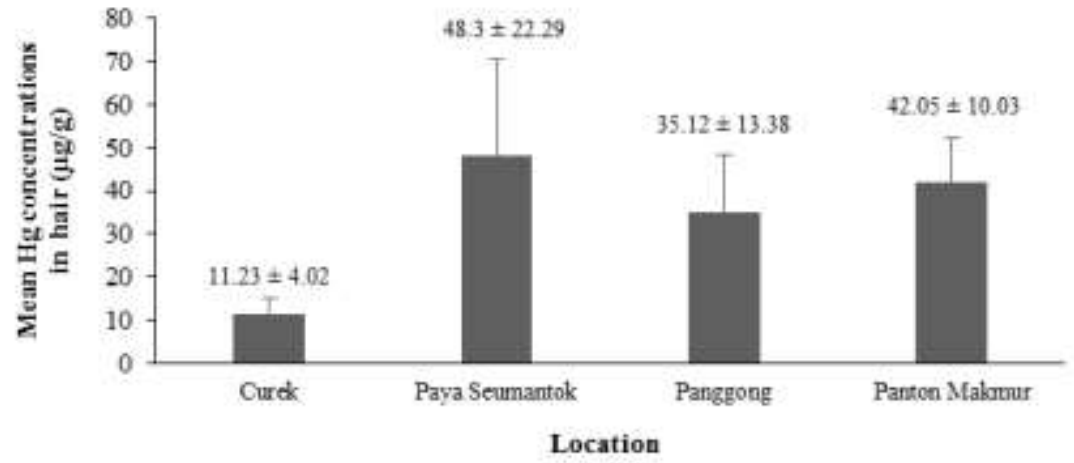

Figure 3. Mean $\mathrm{Hg}$ concentrations in the hair of respondents at four locations in Krueng Sabee

Respondents in Panton Makmur also recorded higher mercury concentration in hair. One reason for this is due to the intensive burning amalgam around the area. When amalgams are heated, anyone in the vicinity can be exposed to mercury vapors. They also specify that approximately $80 \%$ of elemental mercury vapors that are inhaled are absorbed [12]. Activities related to gold processing using mercury give significant contributions to air mercury in the form of elemental mercury $\left(\mathrm{Hg}^{\circ}\right)$. This form of mercury easily enters the human body via the respiratory system of respondents in the area. More industries that are established and active in the area results in more mercury that is inhaled by respondents which can be accumulated in the body. Exposure of mercury vapor from burning amalgam processes also increases mercury concentration in the human body in the area [1]. The inhalation of the vaporized elemental mercury is much more hazardous to human health than ingestion of the liquid form [2].

Based on characteristics of respondents in this study, it was found that there is no significant difference between hair mercury concentrations and sex $(\mathrm{p}>0.05)$ as indicated in Table 1.

Table 1. Mercury Concentrations ( $\mu \mathrm{g} / \mathrm{g})$ in Hair of the Population from Krueng Sabee Sub-district, Aceh Province, Indonesia

\begin{tabular}{lcccc}
\hline \multirow{2}{*}{ Subjects } & $\mathrm{N}$ & Mean of $\mathrm{Hg}$ in hair $(\mu \mathrm{g} / \mathrm{g})$ & \multicolumn{2}{c}{ Range of $\mathrm{Hg}(\mu \mathrm{g} / \mathrm{g})$} \\
& & & Minimum & Maximum \\
\hline Male & 39 & $34.57 \pm 21.25$ & 5.7 & 84.4 \\
Female & 33 & $38.76 \pm 20.09$ & 8.4 & 88.1 \\
Total & 72 & $36.49 \pm 20.69$ & 5.7 & 88.1 \\
\hline
\end{tabular}

Table 1 shows that the total mean $\mathrm{Hg}$ concentrations in the hair samples of respondents were $36.49 \pm 20.69 \mu \mathrm{g} / \mathrm{g}(5.7-88.1 \mu \mathrm{g} / \mathrm{g})$. The safety standard of the WHO tolerance limit of $10 \mu \mathrm{g} / \mathrm{g}$ for mercury was exceeded by $90.28 \%$ of the respondents [10]. This result was different from a study conducted by Kwaansa-Ansah et al. that found there is a significant relationship between hair $\mathrm{Hg}$ and $\operatorname{sex}(\mathrm{p}<0.005)$ [13].

\subsection{Clinical symptoms of mercury in hair}

Respondents from this study were provided with a list of symptoms commonly associated with mercury intoxication. Acute and chronic toxicity symptoms were documented by interviewing the respondents in the Krueng Sabee sub-district. These symptoms were recorded subjectively. Descriptions of acute and chronic symptoms were assessed based on various studies related to mercury's impact on human health around the world [10],[12],[14]-[16]. Acute toxicity symptoms were higher for gold miners compared to non-gold miners. Percentage of acute toxicity symptoms in respondents in the Krueng Sabee sub-district is shown in Figure 4. 


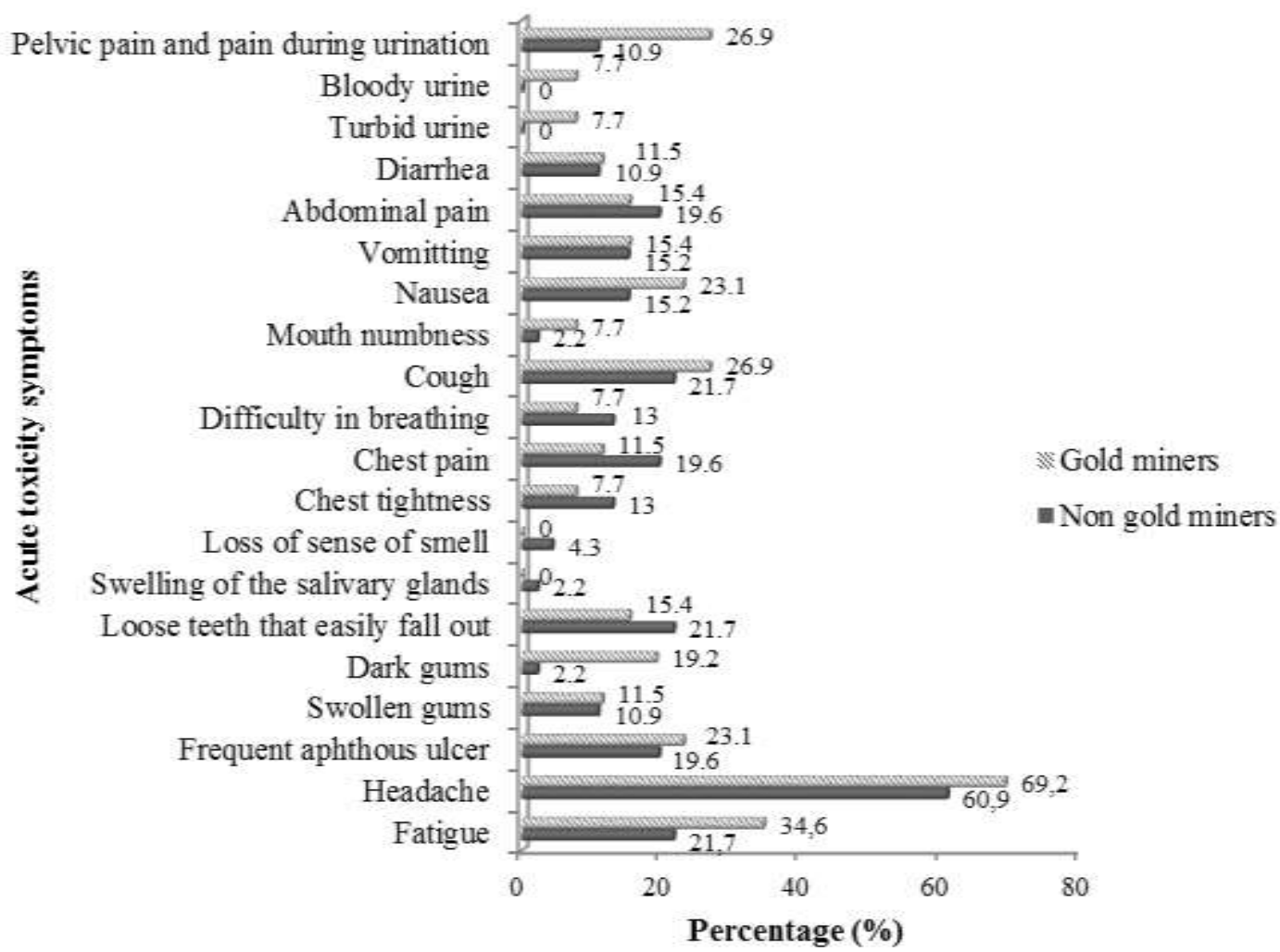

Figure 4. Percentage of acute toxicity symptoms in respondents in Krueng Sabee sub-district, Aceh Province, Indonesia

Figure 4 shows that over half of the respondents had experienced headache, which gold miners had experienced more $(69.2 \%)$ than non-gold miners $(60.9 \%)$. Gold miners were more likely to report experiencing the following symptoms compared to non-gold miners: fatigue (34.6 vs. 21.7\%), pelvic pain and pain during urination (26.9 vs. $10.9 \%)$, bloody urine (7.7 vs. $0 \%)$, turbid urine (7.7 vs. $0 \%)$, cough (26.9 vs. $21.7 \%$ ), frequent aphthous ulcers (23.1 vs. 19.6\%), swollen gums (11.5 vs. 10.9\%), diarrhea (11.5 vs. $10.9 \%)$, mouth numbness (7.7 vs. $2.2 \%$ ), vomiting (15.4 vs. 15.2$)$, nausea (23.1 vs. $15.2 \%$ ), and dark gums (19.2 vs. $2.2 \%)$. Non-gold miners receive less acute toxicity symptoms because they had lower chances to contact with mercury compounds during their activities in mining area. This factor influenced mercury compounds enter the body which can further cause acute toxicity symptoms. However, for non-gold miners, exposure to mercury compounds to their body may happening slowly due to mercury compounds had already exist in the environment (air, water, and seafood). Chemical form of mercury give a different effect on the emergence of health problems in individuals. Toxicity of inorganic mercury to acute inflammation will give symptoms of gastroenteritis, nausea, vomiting, renal dysfunction, abdominal pain, shortness of breath, chest pain, chest tightness, and a dry cough. Mercury in $\mathrm{Hg}^{\circ}$ state, if enters the body, will contribute to acute symptoms in individuals such as coughs, gastrointestinal disturbances such as nausea, vomiting and diarrhea, salivation, weakness, headache and vision problems. Organic mercury which exposed in a high number of individuals will give a complaint of acute gastrointestinal disorders and autistic syndromes [17].

Severe damage to the brain, kidneys, and lungs may result from mercury, depending on the length and intensity of exposure [1]. Acute exposure to mercury vapor may have some central nervous system impacts caused by a small amount of unoxidized $\mathrm{Hg}^{\mathrm{O}}$ that may cross the blood-brain barrier [2]. Common symptoms that may occur within hours of inhalation exposure include a metallic taste in the mouth, fever, chills, dyspnea, nausea,vomiting, diarrhea, and cough along with chest tightness. For chronic toxicity, mercury had caused several symptoms for gold miners and non-gold miners as shown in Figure 5. 


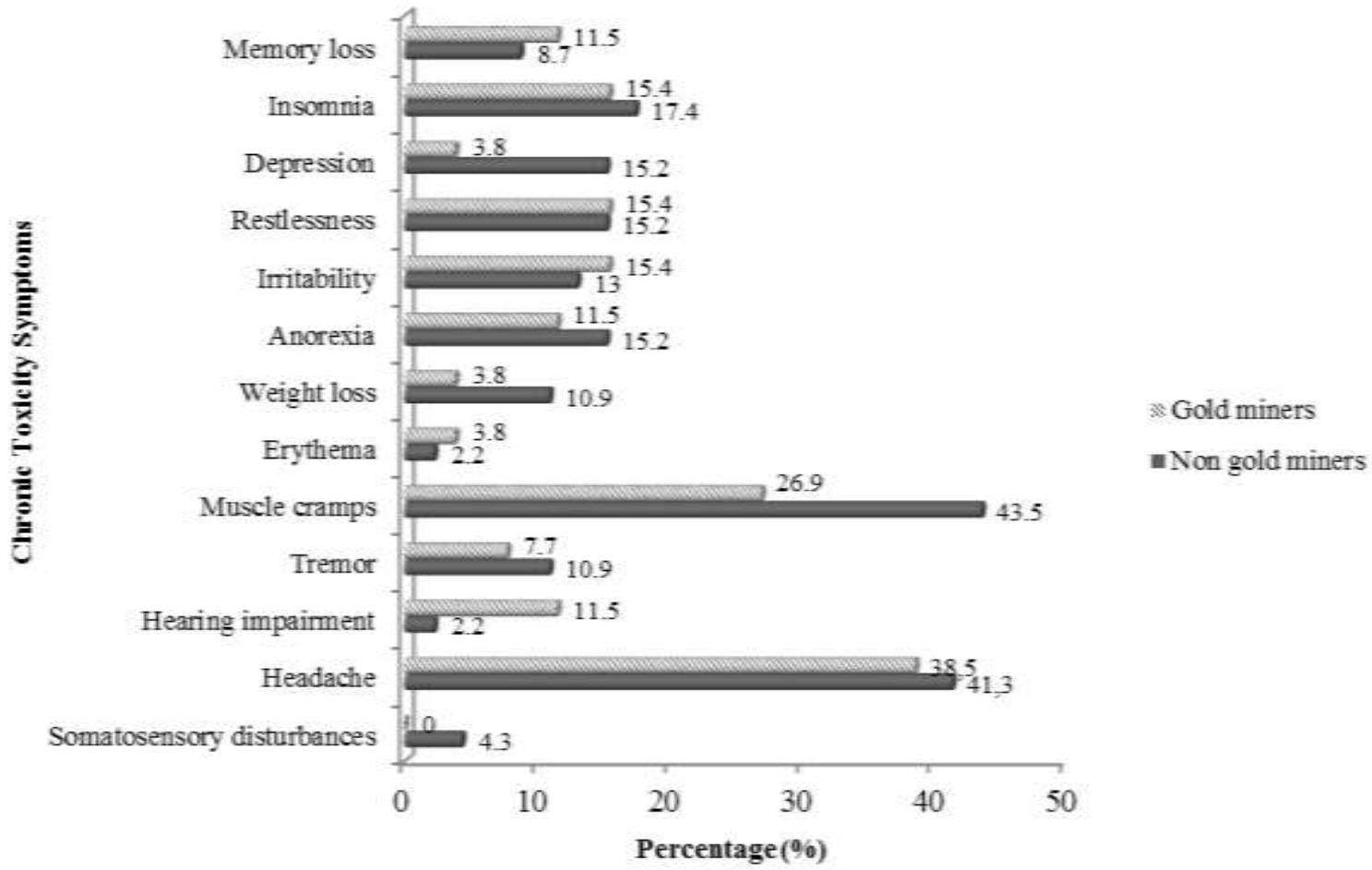

Figure 5. Percentage of chronic toxicity symptoms for respondents in Krueng Sabee sub-district, Aceh Province, Indonesia

Figure 5 shows that percentage of chronic toxicity symptoms for respondents in Krueng Sabee subdistrict, Aceh Province, Indonesia were higher for non-gold miners than gold miners. Over more than a quarter of respondents reported experiencing headache (38.5 vs. $41.3 \%)$ and muscle cramps (26.9 vs. $43.5 \%)$, while insomnia (15.4 vs. 17.4\%), depression (3.8 vs. $15.2 \%$ ), anorexia (11.5 vs. $15.2 \%)$, weight loss (3.8 vs. $10.9 \%)$, tremors (7.7 vs. $10.9 \%)$, and somatosensory disturbances (0 vs. $4.3 \%$ ) were frequently reported for chronic toxicity symptoms. However, symptoms which were higher in gold miners than non-gold miners included memory loss (11.5 vs. $8.7 \%$ ), restlessness (15.5 vs. $15.2 \%)$, and irritability (15.4 vs. $13 \%)$. Shortly after entering the body, mercury quickly becomes tightly bound in the brain, spinal cord, ganglia, autonomic ganglia, and peripherals motor neurons [14].

Transient and residual distribution of mercury has the potential cause to make symptoms in a number of different organ systems. In the central nervous system, mercury can damage the blood-brain barrier. The effects of mercury poisoning in the central nervous system include depression, extreme irritability, memory loss, tremors of the hands, head, tongue, jaw, and eyelids, weight loss, headaches, insomnia, and fatigue. Mercury has also been shown to have various symptoms on other special sensory systems, including hearing loss, a reduced sense of smell, and abnormal touch sensations. For chronic toxicity, the people who work directly with the mercury showing symptoms more quickly in an interval of several weeks while those not directly affected by mercury exposure will experience chronic toxicity after many years [14].

These findings revealed that mercury exposure from small-scale gold mining areas is widespread in Krueng Sabee sub-district in Aceh, Indonesia. All respondents in the area had mercury which was detected in their hair samples. Acute and chronic symptoms which were very close to the effects of mercury exposure were documented in this study area. In general, mercury has shown the impacts on human health based on the high mercury levels found in human hair and seafood in the vicinity. Our findings recommend that preventive interventions are needed to reduce mercury exposure in Krueng Sabee due to small-scale gold mining activities and necessitate the need for options for managing the risks posed by contaminated sites.

\subsection{The Use of personal protective equipment (PPE) among gold miners}

Observations on the use of PPE among gold miners in the Krueng Sabee sub-district show that the gold miners rarely used protective equipment. Table 2 shows the use of PPE among gold miners. 
Table 2. The use of Personal Protective Equipment (PPE) among Gold Miners in Krueng Sabee Sub-district, Aceh Province, Indonesia

\begin{tabular}{lcc}
\hline Personal Protective Equipment & $\begin{array}{c}\text { Frequency of the use of } \\
\text { Personal Protective Equipment } \\
(\mathrm{n}, \%)\end{array}$ & p value \\
\hline Safety helmet & 0 & - \\
Apparel & $1(3,85)$ & 0,003 \\
Glasses & $1(3,85)$ & 0,725 \\
Ear plugs & $1(3,85)$ & 0,374 \\
Gloves & $5(19,23)$ & 0,002 \\
Respirator/Mask & $7(26,92)$ & 0,01 \\
Boots & $14(53,85)$ & 0,306 \\
\hline
\end{tabular}

As shown in Table 2, about $3.85 \%$ of gold miners used apparel, glasses, and ear plugs, while $19.23 \%$ used gloves, and $26.92 \%$ used a respirator/mask. More than half of respondents $(53.85 \%)$ used boots. Foot protectors such as boots were used more $(53.85 \%)$ than any other protectors. None of the miners used head protectors such as safety helmets $(0 \%)$.

The results of this study are similar to Tomicic who also observed the near absence of the use of Personal Protective Equipment [15]. He documented that no respondent wore boots or glasses, and $91 \%$ of respondents reported having repeated skin contact with mercury. Only $2 \%$ of respondents used gloves and $12 \%$ used respiratory protection against dust. Based on statistical analysis, the use of a respirator/mask, gloves, and pack makes a significant difference $(\mathrm{p}<0.05)$ in mercury concentration levels in the hair of gold miners in Krueng Sabee sub-district. It is noted that from these findings, gold miners must protect themselves while working with mercury in gold mining activities.UNEP and WHO recommend that to decrease occupational exposures, we should increase the awareness of possible health impacts to workers, improve work practices to reduce the use and release of mercury, provide better ventilation, better waste management, and support the use of respiratory protective equipment [16].

\section{CONCLUSION}

The contamination of mercury in small-scale gold mining activities in the Krueng Sabee sub-district in Aceh Province, Indonesia has caused harmful impacts to seafood and humans in the area. Mercury in seafood ranging from $27.897 \pm 3.680 \mu \mathrm{gHg} / \mathrm{g}$ to $172.299 \pm 10.626 \mu \mathrm{gHg} / \mathrm{g}$ has the highest concentrations in bottom-feeder fish, shrimp, and mollusc. These values exceed the tolerable limit set by the MoH Food and Drug Administrasionof $0.5 \mu \mathrm{gHg} / \mathrm{g}$. Mercury in human hair was recorded to exceed the safety standard of the WHO tolerance limit of $10 \mu \mathrm{g} / \mathrm{g}$ for $90.28 \%$ of the respondents. Acute and chronic toxicity symptoms due to mercury exposures have been examined and detected in the population. The use of personal protective equipment is urgently needed in the workplace for gold miners in order to reduce the health risks caused by mercury.

\section{ACKNOWLEDGEMENTS}

The authors extend their thanks to all of the respondents and colleagues who were involved in the field study. Special thanks to the staff of the Laboratory Centre for Advanced Analytical Toxicology Services (CAATS), at the University Science of Malaysia in Penang, Malaysia who assisted with the hair sample analysis. The authors would like to thank the Govenment of Aceh and HPEQ Project of Syiah Kuala University, Indonesia for providing financial support.

\section{REFERENCES}

[1] T. W. Clarkson, "The three modern faces of mercury," Environ Health Perspect, vol. 110, pp. 11-23, 2002.

[2] J. C. Clifton, "Mercury Exposure and Public Health," Pediatr Clin N Am, vol. 54, pp. 237-269, 2007.

[3] Suhendrayatna, A. Ohki, A. C. Gultom, "Mercury Levels and Distribution in Organs of Water Organisms from Krueng Sabe River, Aceh Jaya, Indonesia," 6th Annual International Workshop \& Expo on Sumatra Tsunami Disaster \& Discovery in conjuction with 4th South China Sea Tsunami Workshop, 22-24 Nov, pp. 291-294, 2011.

[4] BPS, "Aceh Jaya in Number," Aceh Jaya, Province of Aceh, 2011.

[5] EPA (Environmental Protection Agency), "Guidance for Assessing Chemical Contaminat Data for Use in Fish Advisories: Fish Sampling and Analysis," vol. 1, 1999.

[6] APHA (American Public Health Association), "Standard Methods for the Examination of Water and Wastewater," $18^{\text {th }}$ ed. American Water Works Association and Water Environment Federation, Washington DC, 1992. 
[7] I. B. A. Razagui, S. J. Haswell, "The Determination of Mercury and Selenium in Maternal and Neonatal Scalp Hair by Inductively Coupled Plasma-Mass Spectrometry,” Journal of Analytical Toxicology, vol. 21, 1997.

[8] MAFF, "Monitoring and surveillance of non-radioactive contaminants in the aquatic environment and activities regulating the disposal of wastes at sea," in: Aquatic Environment Monitoring Report No.32. Centre for Environment, Fisheries and Aquaculture Science, Lowestoft, UK., 2000.

[9] J. R. Inzunza, S. B. G. Rosales, F. P. Osuna, "Distribution of mercury in adult penaeid shrimps from AltataEnsenada delPabellon lagoon (SE Gulf of California)," Chemosphere, vol. 57, pp. 1657-1661, 2004.

[10] WHO (World Health Organization), "Elemental Mercury and Inorganic Mercury compounds: Human Health Aspects," International Programme on Chemical Safety, 2003.

[11] C. Y. Chen, N. Serrell, D. C. Evers, B. J. Fleishman, K. F. Lambert, J. Weiss, R. P. Mason, M. S. Bank, "Meeting report: Methylmercury in marine ecosystems-From sources to seafood consumers," Environ Health Perspect, vol. 116, pp. 1706-1712, 2008.

[12] E. E. Yard, J. Horton, J. G. Schier, K. Cald, C. Sanchez, L. Lewis, C. Gastanaga, "Mercury exposure among artisanal gold miners in Madre de Dios, Peru: A cross-sectional study," J. Med. Toxicol, vol. 8, pp. 441-448, 2012.

[13] E. E. K. Ansah, N. Basu, J. O. Nriagu, "Environmental and Occupational Exposures to Mercury Among Indigenous People in Dunkwa-On-Offin, a Small Scale Gold Mining Area in The South-West of Ghana," Bull Environ Contam Toxicol, vol. 85, pp. 476-480, 2010.

[14] K. M. Rice, E. M. Walker Jr, M. Wu, C. Gillette, E. R. Blough, "Environmental Mercury And Its Toxic Effects," J Prev Med Public Health, vol. 47, pp. 74-83, 2014.

[15] C. Tomicic, Vernez D., T. Belem, M. Berode, "Human mercury exposure associated with small-scale gold mining in Burkina Faso," Int Arch Occup Environ Health, vol. 84, pp. 539-546, 2011.

[16] UNEP (United Nations Environment Program) and WHO (World Health Organization), "Guidance for identifying populations at risk from mercury exposures," IOMC, Geneva, Switzerland, August 2008.

[17] M. R. Rahimzadeh, S. Kazemi, A. A. Moghadamnia, "Current Approaches of the Management of Mercury Poisoning: Need of the Hour," DARU Journal of Pharmaceutical Sciences, vol. 22, pp. 1-10, 2014.

\section{BIOGRAPHIES OF AUTHORS}

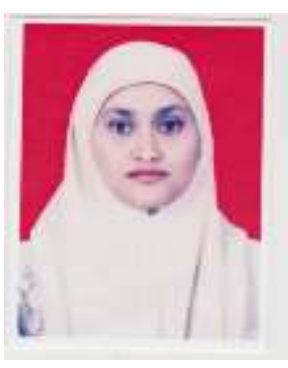

Sofia born in Banda Aceh, Indonesia,November $4^{\text {th }}$ 1974. Received the B.E. degree in chemistry from the Syiah Kuala University, Indonesia, in 1997, and the M.Sc degree in Pollution and Toxicology Department, University Science Malaysia (USM), Penang, Malaysia in 2005. In 2016 she obtained PhD degree from Faculty of Medicine, Gadjah Mada University, Indonesia. She starts as lecturer in Medical Chemistry and Biochemistry Department of Faculty of Medicine, Syiah Kuala University, Aceh, Indonesia since 1999 until present. Her current research interests include environmental health, disaster management, applied chemistry, pollution and toxicology, herbal medicine, climate change, occupational health, public health issues, and medical education. Secretary of Health Profesional Education and Quality (HPEQ) Project in 2009, Senate Commission of Collaboration at Syiah Kuala University (2012-present), Member of Accreditation's board of Syiah Kuala University (2010-2014), Secretary of Centre for Health Service Management (CHSM), Faculty of Medicine, Syiah Kuala University, member of Quality Assurance, Satya Lencana Karya Satya in 2013. Currently (2016), she acts as Head of Centre for Education Development, LP3M, at Syiah Kuala University.

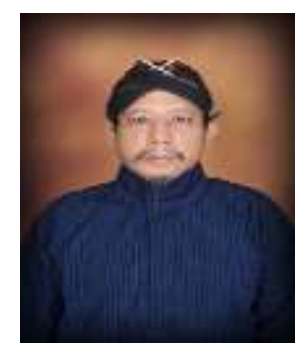

Adi Heru Husodo born in Kediri,Jawa Timur, October $9^{\text {th }}, 1957$. Graduate degree from Faculty of Medicine, Gadjah Mada University, in 1984. Master of Science (M.Sc) in Medical Demography, University of London, England, in 1989. Diploma in the Community Nutrition (DCN), South East ASEAN Minister of Education Organization (SEAMEO), University of Indonesia in 1995. Diploma in the London School of Hygiene \& Tropical Medicine (DLSHTM), University of London, England, 1997. Diploma in English dari the New School of English, Cambridge, UK. Doctoral in Public Health and specifically in Environmental \& Occupational Health from Airlangga University, Surabaya, JawaTimur, in 2001. Professor in Public Health. As reviewer, expert editor of some international and local journals. Many articles published at national and international journals. Writers for modules of Environmental Health in 2010, Occupational Health in 2009 and 2010, books of Obstetric and Gynecology Epidemiology in 2010, Research Methodology in 2011, Occupational Health in 2011, Occupational Productivity Bioengineering on 2011, Weekly Clinical Updates On Primary Care Instructions Book. Awardee for Innovation Award from Indonesian Global Foundation and Minister of Communication and Information of the Republic of Indonesia, in 2011, Third Lyn Clearihan Awardat Jeju International Convention Center, Jeju, Korea during the $19^{\text {th }}$ Wonca Asia Facific Regional Conference. Very active in many community services related to public health.Chief of Family Medicine Team at Faculty of medicine, Gadjah Mada University, Chairman of Association of Family Doctor Yogyakarta Branch,Chairman of Indonesian Red Cross Yogyakarta Branch (2005-2015). 


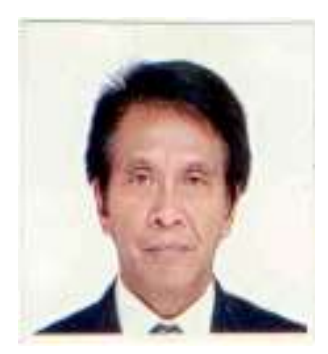

Eko Sugiharto born in Panarukan, December $10^{\text {th }}, 1949$. B.Sc degree in chemistry, 1980, DEA in Environmental Chemistry, Universite Louis Pasteur, Strasbourg, French, 1985, Doctor in Environmental Chemistry, Universite Louis Pasteur, Strasbourg, French, 1988. Many Courses and trainings attended were related environmental impact assesment, cleaner production, environmental management, environmental auditor. Lecturer in Chemistry Department, Gadjah Mada University from 1980 until now. Concentrate in analystical chemistry, toxicology, spectrometri, quality assurance, environmental chemistry, environmental management systems, separation chemistry. Expert in Environmental Impact Analysis (2012-now). Coordinator of Water Qualityin Yogyakarta (1997-now), Environmental Pollution (199-now), Assesor for Environmental Impact Analysis (2003-now). Several research have been done related environmental analysis and development. As a head of centre for environmental studies, Gadjah Mada University (2006-2010). 